\title{
Analysis of changes in the system of identification and classification of soils
}

\author{
Maria Jolanta Sulewska ${ }^{1, *}$ \\ ${ }^{1}$ Bialystok University of Technology, Department of Civil and Environmental Engineering, Wiejska 45A St., Bialystok, Poland
}

\begin{abstract}
The objective of the article is to analyse the proposed changes in the European and international principles of the system of identification and classification of soils, included in Final Draft International Standards: ISO/FDIS 14688-1:2017 and ISO/FDIS 14688-2:2017, which will probably be introduced in 2018 or 2019 .
\end{abstract}

\section{Introduction}

The current rules for identification of soil and classification testing are described in the following Polish, European and international standards: PN-EN ISO 146881:2006 [1] together with the amendment of PN-EN ISO 14688-1:2006/Ap1:2012, and PN-EN ISO 14688-2:2006 [2] with amendments: PN-EN ISO 14688-2/Ap1:2010 (withdrawn in 2012) and PN-EN ISO 146882:2006/Ap2:2012, and change of PN-EN ISO 146882:2006/A1:2014. As standards related to PN-EN 19972:2009 Eurocode 7-2 [3], they are in force in Poland pursuant to the Regulation of the Minister of Transport, Construction and Maritime Economy of 25.04.2012 regarding the determination of geotechnical conditions for setting of building structures [4] .

In 2017, comments on the content of the projects were filed and voting carried out in the Standardisation Committees of the Member States of the European Committee for Standardisation (CEN) on the final draft of the revised classification standards (Final Draft International Standards): ISO/FDIS 14688-1:2017 [5] and ISO/FDIS 14688-2:2017 [6]. In 2018 or 2019, the adoption and introduction of changes in the rules for classification and soil classification studies is planned.

The aim of the article is to analyse selected, most important changes in international principles of soil classification and geotechnical classification testing in relation to the European standards applied so far: EN ISO 14688-1:2002 [7] and EN ISO 14688-2:2004 [8].

\section{Testing for classification of soils}

\subsection{Scope}

The rules for determining (classifying) and describing the soil for engineering purposes are included in Final Draft International Standard ISO/FDIS 14688-1:2017 [5]. The standard applies to in-situ native mineral soils or to in-situ anthropogenic soils, and to displaced soils.

\footnotetext{
*Corresponding author: m.sulewska@pb.edu.pl
}

The following definitions of soils have been introduced: anthropogenic soil, carbonate soil, fill, loess, made ground and reconstituted ground, mineral and organic soil, sulphide soil, till. In Polish conditions, a group of post-glacial soils is important, described as till -original form of glacigenic multi-graded material derived from ice sheets and glaciers.

The definition of plasticity (plastic behaviour) has changed - currently it denotes: a propensity of fine soil to undergo permanent deformation when kneaded by hand. The names and ranges of the fraction diameters have not changed; the symbols of the main fractions changed slightly, for example from CSa to cSa or from FSi to fSi.

\subsection{Identification of soils}

Soils have been identified as aggregate of minerals and/or organic materials which can be disaggregated by hand in water [5]. They comprise primary fraction, secondary and tertiary fractions. Soils are categorised as natural or anthropogenic soils. Natural soils are either mineral soils (including carbonate soils, volcanic soils, loess and till) or organic soils.

The primary fraction in terms of mass (very coarse or coarse soils) or plastic behaviour (fine soils) determines the engineering properties of the soil.

Secondary fractions modify the engineering properties of the primary soil fraction.

Tertiary constituents do not affect the engineering behaviour of the soil, but they are important in assisting in the identification of the origin of the soil (shell fragments, glauconite grains, iron sulphides, plant remains and rootlets, calcareous).

The identification procedure for the mineral soil follows the steps:

a) categorization of soil into subcategories: very coarse soil (BOULDERS and COBBLES), coarse soil (GRAVEL and SAND) and fine soil (SILT and CLAY), b) identification of primary, secondary and tertiary fractions, 
c) naming of the soil: the secondary fractions as adjectives shall by placed with the term describing the primary fraction in the order of increasing proportion; it is not mandatory to write the name of the soil with the symbols of fractions; the names of primary fractions are written in capital letters, and the secondary and tertiary fractions are usually in the form of an adjective, in examples: coarse sandy fine GRAVEL, fine gravelly silty coarse SAND, fine gravelly coarse sandy SILT, slightly medium sandy CLAY

d) identification of the origin of the deposit in terms of the depositional environment and geological age.

Identification of very coarse and coarse mineral soils shall be made on the basis of the particle size fractions.

The identification of fine soil shall be made on the basis of the soil plasticity.

Flow chart for the identification and description of primary fractions has not changed essentially. The additional descriptions under the flow chart were extended and a list of activities performed in order to classify and characterise the tested soil was included, depending on the assignment to a specific group of soils: VERY COARSE and COARSE SOIL, FINE SOIL, ORGANIC SOIL, ANTHROPOGENIC SOIL.

The basic procedures for identification of the primary fraction (and others) in soils are macroscopic tests. Laboratory tests should complement macroscopic field tests.

\subsection{Field assessment of fine soils}

The basic fine soil fraction is determined by the results of eight macroscopic (manual) tests [5] (Table 1):

Dilatancy - testing a 25-mm diameter ball from the soil of consistency of putty to determine the rate of water on its surface during shaking and finger pressing: none, slow, or rapid,

Toughness - rolling the ground into a thread with a diameter of approx. $3 \mathrm{~mm}$; rolling process should be repeated until the thread breaks up after reaching a diameter of $3 \mathrm{~mm}$. Also, an effort needed to compose the thread should be estimated. After the thread crumbles, mould the pieces together by hand and knead them until the newly formed lump crumbles. Describe the toughness of the thread and lump as: low, medium, or high.

Plasticity - on the basis of observations made during the toughness, describe the plasticity according to the Table 2: non-plastic and plastic (low, medium, high).

Dry strength - of the dry balls with a diameter of about $12 \mathrm{~mm}$ by crushing between the fingers: none, low, medium, high, or very high.

Feel - rubbing between fingers: clays fell smooth and readily take a polish when smeared with a blade or thumb; silts feel silky.

Behaviour in water - place a soil ball in a vessel with water: silt will disintegrate within a few minutes, clay will remain unchanged for much longer.

Behaviour in air - smear moist soil over a smooth surface (glass, plastic, or on the back of the hand): once dry, the silt can be easily brushed off and will tend to form dust, clay will tend to stick and form flakes when brushed.
Cohesion - squeezing of a $25 \mathrm{~mm}$ diameter ball between fingers: a clay will deform in a plastic manner without rupture, a silt will tend to crumble rather than deform.

Table 1. Manual test results for the determination of the primary fine fraction.

\begin{tabular}{|l|l|l|}
\hline \multicolumn{1}{|c|}{ Test } & \multicolumn{1}{c|}{ SILT } & \multicolumn{1}{c|}{ CLAY } \\
\hline Dilatancy & Slow to rapid & None \\
\hline Toughness & $\begin{array}{l}\text { Low toughness } \\
\text { or thread cannot } \\
\text { be formed }\end{array}$ & High \\
\hline Plasticity & $\begin{array}{l}\text { Non-plastic to } \\
\text { low plasticity }\end{array}$ & High \\
\hline $\begin{array}{l}\text { Dry } \\
\text { strength }\end{array}$ & None to low & High to very high \\
\hline Feel & $\begin{array}{l}\text { Silky, sounds } \\
\text { gritty }\end{array}$ & $\begin{array}{l}\text { Smooth, sticky (when } \\
\text { wet) }\end{array}$ \\
\hline $\begin{array}{l}\text { Behaviour } \\
\text { in water }\end{array}$ & $\begin{array}{l}\text { Disintegrates } \\
\text { rapidly in water }\end{array}$ & $\begin{array}{l}\text { Disintegrates slowly if at } \\
\text { all }\end{array}$ \\
\hline $\begin{array}{l}\text { Behaviour } \\
\text { in air }\end{array}$ & $\begin{array}{l}\text { Dries quickly, } \\
\text { brushes off }\end{array}$ & $\begin{array}{l}\text { Dries slowly with } \\
\text { shrinkage }\end{array}$ \\
\hline Cohesion & $\begin{array}{l}\text { Slumps, } \\
\text { moisture drains }\end{array}$ & $\begin{array}{l}\text { Deforms without rupture. } \\
\text { Maintains shape and } \\
\text { moisture during handling }\end{array}$ \\
\hline
\end{tabular}

Table 2. Plasticity of soil.

\begin{tabular}{|l|l|}
\hline \multicolumn{1}{|c|}{ Term } & \multicolumn{1}{c|}{ Criteria } \\
\hline Non-plastic & $\begin{array}{l}\text { A } 3 \mathrm{~mm} \text { thread cannot be rolled at any water } \\
\text { content }\end{array}$ \\
\hline Low & $\begin{array}{l}\text { The thread can barely be rolled and the lump } \\
\text { cannot be formed when drier than the plastic } \\
\text { limit }\end{array}$ \\
\hline Medium & $\begin{array}{l}\text { The thread is easy to roll and not much time is } \\
\text { required to reach the plastic limit; the thread } \\
\text { cannot be rerolled after reaching the plastic } \\
\text { limit, and the lump crumbles when drier than } \\
\text { the plastic limit }\end{array}$ \\
\hline High & $\begin{array}{l}\text { It takes considerable time rolling and kneading } \\
\text { to reach the plastic limit; the thread can be } \\
\text { rolled several times after reaching the plastic } \\
\text { limit, and the lump can be formed without } \\
\text { crumbling when drier than the plastic limit }\end{array}$ \\
\hline
\end{tabular}

For comparison, Table 3 presents a description of macroscopic examinations according to the currently valid EN ISO 14688-1:2002 [7], which recommends six macroscopic examinations to identify fine-grained soils.

\subsection{Consistency of a fine soils}

The consistency of naturally moist fine soils should be described on the basis of the manual tests: pressing the finger into the soil sample, kneading with fingers, rolling (Table 4).

The standard also provides a description of how to determine the colour and smell of soils, in particular organic soils. 
Table 3. Manual test results for the determination of the primary fine fraction according EN ISO 14688-1:2002 [7].

\begin{tabular}{|c|c|c|c|}
\hline \multicolumn{2}{|c|}{ Test } & SILT & CLAY \\
\hline \multicolumn{2}{|c|}{ Dilatancy } & Slow to rapid & None \\
\hline \multicolumn{2}{|l|}{ Plasticity } & Low plasticity & High \\
\hline \multicolumn{2}{|c|}{ Dry strength } & Low & High \\
\hline \multirow[t]{2}{*}{$\begin{array}{l}\text { Determi } \\
\text {-nation } \\
\text { of sand, } \\
\text { silt } \\
\text { and } \\
\text { clay } \\
\text { content }\end{array}$} & $\begin{array}{l}\text { Rubbing } \\
\text { between the } \\
\text { fingers }\end{array}$ & $\begin{array}{l}\text { Feels soapy and } \\
\text { sticks to the } \\
\text { fingers and cannot } \\
\text { be removed } \\
\text { without washing, } \\
\text { even when in the } \\
\text { dry state }\end{array}$ & $\begin{array}{l}\text { Feels smooth } \\
\text { to the touch, } \\
\text { the dry soil } \\
\text { particles that } \\
\text { stick to the } \\
\text { fingers can be } \\
\text { easily blown } \\
\text { away }\end{array}$ \\
\hline & $\begin{array}{l}\text { Cutting with } \\
\text { a knife or } \\
\text { scoring with } \\
\text { a fingernail }\end{array}$ & A dull cut surface & $\begin{array}{l}\text { A shiny cut } \\
\text { surface }\end{array}$ \\
\hline
\end{tabular}

Table 4. Description of consistency [5].

\begin{tabular}{|l|l|}
\hline Term & \multicolumn{1}{|c|}{ Criteria } \\
\hline $\begin{array}{l}\text { Very } \\
\text { soft }\end{array}$ & $\begin{array}{l}\text { Finger can be easily pushed in up to 25 mm, and soil } \\
\text { exudes between the fingers when squeezed in the } \\
\text { hand }\end{array}$ \\
\hline Soft & $\begin{array}{l}\text { Finger can be pushed in up to } 10 \mathrm{~mm} \text {, and soil can be } \\
\text { moulded by light finger pressure }\end{array}$ \\
\hline Firm & $\begin{array}{l}\text { Thumb makes an impression easily; soil cannot be } \\
\text { moulded by fingers, but rolls in the hand to } 3 \mathrm{~mm} \\
\text { thick threads without breaking or crumbling }\end{array}$ \\
\hline Stiff & $\begin{array}{l}\text { Soil can be intended slightly by thumb; soil crumbles } \\
\text { and breaks when rolling to 3 mm thick threads but is } \\
\text { still sufficiently moist to be moulded to a lump again }\end{array}$ \\
\hline $\begin{array}{l}\text { Very } \\
\text { stiff }\end{array}$ & $\begin{array}{l}\text { Soil can be intended by thumb nail; soil cannot be } \\
\text { moulded but crumbles under pressure }\end{array}$ \\
\hline
\end{tabular}

\subsection{Organic soils}

Organic soils are described in Table 5.

Table 5. Description of organic soils [5].

\begin{tabular}{|c|c|c|}
\hline Term & Type & Description of organic soil \\
\hline \multirow[t]{3}{*}{ PEAT } & Fibrous & $\begin{array}{l}\text { Fibrous structure, easily recognisable plant } \\
\text { structure, retains some strength }\end{array}$ \\
\hline & $\begin{array}{l}\text { Pseudo- } \\
\text { fibrous }\end{array}$ & Mixture of fibres and amorphous paste \\
\hline & $\begin{array}{l}\text { Amor- } \\
\text { phous }\end{array}$ & $\begin{array}{l}\text { No visible plant structure, mushy } \\
\text { consistency }\end{array}$ \\
\hline \multicolumn{2}{|c|}{$\begin{array}{l}\text { TOPSOIL } \\
\text { or HUMUS }\end{array}$} & $\begin{array}{l}\text { Plant remains, living organisms and their } \\
\text { excretions together with inorganic } \\
\text { constituents }\end{array}$ \\
\hline \multicolumn{2}{|c|}{ GYTTJA } & $\begin{array}{l}\text { Sediment formed in nutrient-rich water } \\
\text { and mainly consisting of more or less } \\
\text { decomposed remains of plants and animals } \\
\text { (detritus) }\end{array}$ \\
\hline \multicolumn{2}{|l|}{ DY } & $\begin{array}{l}\text { Sediment formed in nutrient-poor water } \\
\text { and mainly consisting of precipitated } \\
\text { colloidal humic substances (dry matter) }\end{array}$ \\
\hline
\end{tabular}

\subsection{Other soil types}

ISO/FDIS 14688-1:2017 [5] specifies rules for the identification and description of other soils of various origins, such as: carbonate soils with the testing of carbonate content (non-calcareous, slightly calcareous, calcareous, highly calcareous); sulfide soils; volcanic soils with particle size fractions; loess; glacial soils; anthropogenic soils: fill (controlled placement), made ground/reconstituted ground (uncontrolled placement) und description of fabric and artefacts. It also includes description guidelines for bedding and discontinuities with bedding thickness terms and discontinuity spacing terms, and interbedding, and mixed soil.

\section{Principles for a soil classification}

The rules for categorising soils into groups of similar structure and similar properties are given in the Final Draft International Standard ISO/FDIS 14688-2:2017 [6].

The following sections of the Standard has not been changed: terms and definitions, classification of soils with particle sizes $\leq 2 \mathrm{~mm}$ with organic constituents, correlations to classify relative density using density index $I_{\mathrm{D}}$, undrained shear strength of fine soils, consistency index $I_{\mathrm{C}}$ of silts and clays. The classifications given below have been changed.

\subsection{Particle size distribution (grading)}

First of all, the EN ISO 14688-2:2004 [8] has been reduced by removing the entire Annex B containing: Example of classification of soil, based on grading alone and ISO triangle, as well as Table B.1 - Guiding values for the division of mineral soils on a basis of the contents.

Table 1 - Principles of soils classification in ISO/FDIS 14688-2:2017 [6] has been corrected, especially the following names of soils referred to in symbols, names in words, e.g.: GRAVEL with cobbles, SAND with clay, sandy gravelly SILT, clayey SILT, organic CLAY, sandy clayey GYTTJA.

The particle sizes and their distribution (grading curve) in a soil can be determined by analysis carried out in accordance with ISO 17892-4 (current version [9]) by sieving or sedimentation.

On the base of the uniformity coefficient $C_{\mathrm{U}}$ and the coefficient of curvature $C_{\mathrm{C}}$ shape of grading curve can be determined: uniformly graded (when $C_{\mathrm{U}}<3$ and $C_{\mathrm{C}}<1$ ), poorly graded (when $C_{\mathrm{U}}=3$ to 6 and $C_{\mathrm{C}}<1$ ), medium graded (when $C_{\mathrm{U}}=6$ to 15 and $C_{\mathrm{C}}<1$ ), well graded (when $C_{\mathrm{U}}>15$ and $C_{\mathrm{C}}=1$ to 3 ), gap graded (when $C_{\mathrm{U}}>15$ and $\left.C_{\mathrm{C}}<0.5\right)$.

\subsection{Plasticity}

The classification of fine soils or fine fractions in composite coarse soils should be made in accordance with their plasticity (liquid limit $w_{\mathrm{L}}$ and plastic limit $w_{\mathrm{P}}$ ) which shall be determined by laboratory testing in accordance with ISO 17892-12:2004 [10] (Polish version: PKN-CEN ISO/TS 17892-12:2009; currently a draft ISO/FDIS 17892-12 has been prepared). The plasticity of fine soils should be classified using plasticity chart, which for $\mathrm{Cl}$ and $\mathrm{Si}$ has been categorised into plasticity scope depending on plasticity index $I_{\mathrm{P}}$ and liquid limit $w_{\mathrm{L}}$ : low 
$\mathrm{L}$, medium $\mathrm{M}$, high $\mathrm{H}$, very high $\mathrm{V}$, possibly with an additional symbol $\mathrm{O}$ - organic, e.g.: $\mathrm{ClM}, \mathrm{SiH}, \mathrm{ClHO}$ [6].

\subsection{Sensitivity}

Fine soil may also be classified in accordance with their sensivity [6]: low (when sensivity < 8), medium (when sensivity $=8$ to 30 ), high (when sensivity $>30$ ). Sensivity it is the ratio between the undisturbed and remoulded undrained shear strength.

\section{Discussion}

European soil classification has been valid in Poland since 2006, and applied according to the following standards: PN-EN ISO 14688-1:2006 [1] and PN-EN ISO 146882:2006 [2]. In 2012, the entire first National Annex, included in PN-EN ISO 14688-2:2006 [2] was withdrawn (the "new Polish" triangle and Polish word names of soils were withdrawn) and the second, currently applicable National Annex, included in PN-EN ISO 146882:2006/Ap2:2012 [2] was introduced.

The purpose of the new soil classification standard was to create a uniform European system for classifying and soil classification testing, enabling easy international communication between geotechnicians.

The introduction of the new soil classification has aroused numerous discussions and doubts in the Polish geotechnical community. The previous "old" Polish soil classification system with the "new" European system was compared and the differences and similarities between both systems were analysed. Many a critical remarks were assigned to the new classification of soils, and inaccuracies and errors in the content of the standard were noted [11-18].

The most frequent doubts were soil classification on the basis of grain size using the new ISO triangle test included in PN-EN ISO 14688-2:2006 [2]. It was noticed that especially in the border areas between two groups of soil, it is difficult to clearly determine its name [11-12, 1415]. It was found that the classification of soils on the basis of grain size distribution is not consistent with macroscopic recognition, and the use of the ISO triangle is complicated and raises numerous doubts [15, 17-18].

The "Polish triangle" was critically analysed along with a table with "new" Polish names $[11,13,16]$. After the discussion in the geotechnical community, the National Annex was changed and the "Polish triangle" and Polish soil names were withdrawn, and the macroscopic assessment of soil moisture, principles of creating Polish soil names, soil genesis symbols were introduced [2].

An important drawback of the previous "new" European classification system is the inability to develop a key for a simple transition from the name of the soil according to PN-B-02480:1986 [19] to the name of the soil according to PN-EN ISO 14688-1, 2:2006 [1-2] (and vice versa) without knowledge of the grading curve. This resulted in the loss of the possibility of using post-war research achievements and archival results of Polish geotechnical and geological investigations [17].
Interesting proposals were presented [17-18] to adjust the names of soil according to the "old" Polish classification by PN-B-02480:1986 [19] with the nomenclature according to the "new" European classification according to PN-EN ISO 14688-1, 2:2006 [1-2]. The proposals concerned mainly the naming and classification of soils based on their grain size, assuming that the classification based on granulometric composition is more accurate than the classification based on the results of macroscopic studies.

In order to integrate the soil nomenclature according to the "old" Polish classification [19] and the European classification [7] Gołębiewska proposed to divide the clay fraction into three subfractions: $\mathrm{CCl}, \mathrm{MCl}$ and $\mathrm{FCl}$ [17]. In this way, it would be possible to change from the Polish classification of cohesive soils to the European classification. In the case of coarse soils, the Polish classification, after minor adjustments, corresponds to the European classification of fine soils [19]. The author has also proposed Polish soil names, corresponding to the symbolic names of soil according to [7-8].

Tarnawski [18] proposed to use the "old" Polish macroscopic tests for cohesive soils and the "old" Feret's triangle, used so far in Poland according to [19] with applied soil names according to [1-2] (Fig. 1). The author also proposed Polish soil names, corresponding to the European nomenclature.

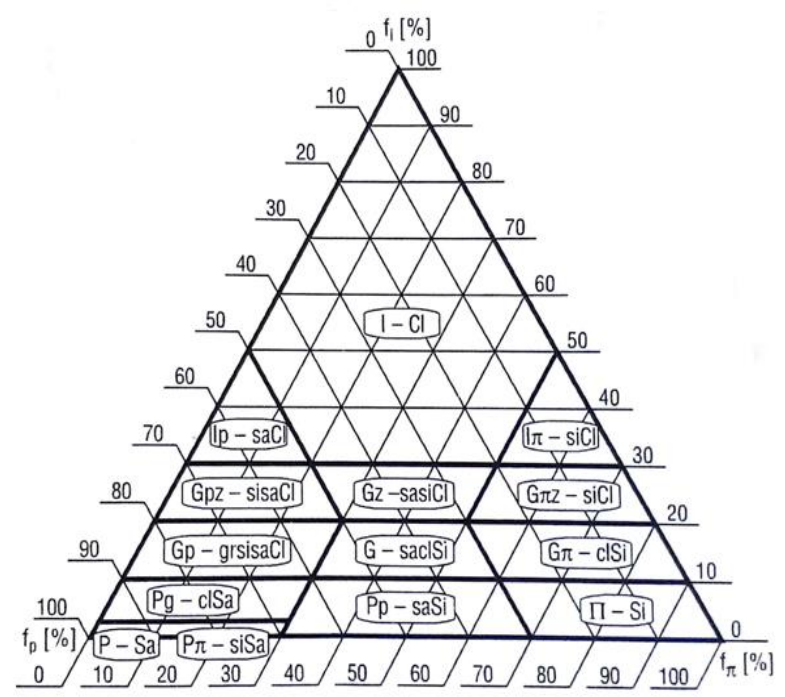

Fig. 1. The Feret's triangle with soil names according to [1-2] and obsolete Polish names of cohesive soil [18].

The latest projects of European classification standards [5-6] seem to have eliminated most of the dilemmas by removing the ISO triangle and eliminating the possibility of naming only on the basis of soil grain size distribution.

The classification of soils and their description is based mainly on the results of macroscopic tests. It is intended that laboratory test should be used to complement the field methods and complete the identification of the soil. 


\subsection{Advantages of proposed classification}

The proposed new classification system of soils and soil classification [5-6] testing system have a number of advantages:

a) flow chart for the identification and description of soils is simple and clear, and includes tests of basic soil groups,

b) the classification has been supplemented with testing and additional descriptions of important properties of the soils, and in particular of specific soils,

c) the names of the soils have been shortened to the primary and secondary fraction, and possibly to the tertiary fraction; showing how to read and write specific names of soil and in this way avoiding ambiguity in naming the soil,

d) the emphasis is on verbal names of the soil, not on their record by means of a sequence of symbols denoting fractions; in practice, it may be more convenient to use the record of soil names by means of symbols (according to established rules of recording).

\subsection{Shortfalls of proposed classification}

The proposed new classification system of soils and soil classification testing also presents some drawbacks:

a) there is no clear division into non-cohesive and cohesive soils,

b) there is no description of the macroscopic examination and classification of soils depending on natural moisture, c) eight types of macroscopic examination of fine soils were introduced instead of five tests; they are still very subjective - following the standard description of the implementation, some of these tests can be carried out practically in any way; some tests are time-consuming, d) in ISO/FDIS 14688-2 [6] there is a definition: liquid limit $\left(w_{\mathrm{L}}\right)$ it is water content at which a fine soil passes from the liquid to the plastic conditions; the definition of liquidity index $\left(I_{\mathrm{L}}\right)$ is also given ; the conditions of fine soils have not been specified; there is also no liquid consistency ; the liquidity index is nowhere to be found in the content of standards [6-7],

e) soil classification and determination of its name is based only on the results of macroscopic studies, it seems, however, that it is not possible to distinguish three silty fractions from each other [5]: coarse silt (cSi) from the medium silt $(\mathrm{mSi})$ and fine silt (fSi); therefore, there should be only one fraction: silt $(\mathrm{Si})$,

f) in ISO/FDIS ISO 14688-2:2017 [6], the following errors were noted: in Table 2 - for uniformly graded is $\mathrm{C}_{\mathrm{U}}<$, and should be $\mathrm{C}_{\mathrm{U}}<3$; in Figure 1 is $\mathrm{ClE}$, and should be $\mathrm{ClV}$.

\section{Conclusions}

On the analysis of the proposed changes included in the final drafts of ISO/FDIS 14688-1, 2:2017 standards [56] the following conclusions can be drown.

- Changes in soil classification standards are going in the right direction; it seems that $\mathrm{CEN}$ has taken into account comments sent by the Standards Committees of the member countries.

- The proposed European soil classification is based only on the results of macroscopic tests which are subject to continuous refinement and alterations.

- It seems that the assumption that the precise name of the soil is not decisive, because geotechnical field and laboratory tests of geotechnical parameters needed for design should be performed for objects in Geotechnical Category 2 and 3.

- Still, there remains the problem of objects in Geotechnical Category 1, for which it would be possible to use archival materials or previously developed dependencies and tables for Polish soils. And for this purpose, a way to adapt (even the approximate) of the "old" Polish classification to the new European classification should be elaborated, while the interesting proposals of Gołębiewska [17] and Tarnawski [18] should be considered here.

- After the entry into force of the revised classification standards, a new Polish National Annex should be developed.

This work, carried out at Bialystok University of Technology, was supported by Polish Ministry of Science and Higher Education (project S/WBiIŚ/2/2018).

\section{References}

1. A. Mecke, I. Lee, J.R. Baker jr., M.M. Banaszak Holl, B.G. Orr, Eur. Phys. J. E 14, 7 (2004)

2. Polish Standard PN-EN ISO 14688-1:2006 Badania geotechniczne - Oznaczanie i klasyfikowanie gruntów - Część 1: Oznaczanie i opis + PN-EN ISO 14688-1:2006/Ap1:2012

3. Polish Standard PN-EN ISO 14688-2:2006 Badania geotechniczne - Oznaczanie i klasyfikowanie gruntów - Część 2: Zasady klasyfikowania + PN-EN ISO 14688-2/Ap1:2010 + PN-EN ISO 14688$2: 2006 / \mathrm{Ap} 2: 2012+\mathrm{PN}-\mathrm{EN}$ ISO 146882:2006/A1:2014

4. Polish Standard PN-EN 1997-2:2009 Eurokod 7-2 Projektowanie geotechniczne - Część 2: Rozpoznanie i badanie podłoża gruntowego

5. Rozporządzenie Ministra Transportu, Budownictwa i Gospodarki Morskiej z dnia 25.04.2012 roku w sprawie ustalania geotechnicznych warunków posadawiania obiektów budowlanych

6. Final Draft International Standard ISO/FDIS 146881:2017 Geotechnical investigation and testing Identification and classification of soil - Part 1: Identification and description

7. Final Draft International Standard ISO/FDIS 146882:2017 Geotechnical investigation and testing Identification and classification of soil - Part 2: Principles for a classification

8. European Standard EN ISO 14688-1:2002 Geotechnical investigation and testing - 
Identification and classification of soil - Part 1: Identification and description

9. European Standard EN ISO 14688-2:2004 Geotechnical investigation and testing Identification and classification of soil - Part 2: Principles for a classification

10. International Standard ISO 17892-4:2016 Geotechnical investigation and testing - Laboratory testing of soil - Part 4: Determination of particle size distribution

11. International Standard ISO/TS 17892-12:2004 Geotechnical investigation and testing - Laboratory testing of soil - Part 12: Determination of Atterberg limits

12. M. Jaros, K. Majer, Porównanie klasyfikowania gruntów spoistych według nowej normy PN-EN ISO i dawnej polskiej klasyfikacji, Zeszyty Naukowe Politechniki Białostockiej, Budownictwo, 29 (2006)

13. A. Gołębiewska, A. Wudzka, Nowa klasyfikacja gruntów według normy PN-EN ISO, Geoinżynieria drogi mosty tunele, 4 (2006)

14. S. Garwacka-Piórkowska, Określenie rodzajów gruntów według PN-EN ISO 14688-1, 2:2006 na podstawie składu granulometrycznego, Inżynieria i Budownictwo, 10 (2010)

15. M.J. Sulewska, Nowa klasyfikacja gruntów, Sci. Rev. Eng. Env. Sci., 25, 3 (2016)

16. A. Gołębiewska, Uwagi krytyczne do klasyfikacji gruntów według normy PN-EN ISO 14688:2006, Biuletyn Państwowego Instytutu Geologicznego, 446 (2011)

17. M. Tarnawski, U. Sykuła, M. Ura, Problemy $\mathrm{z}$ nazewnictwem gruntów spoistych według normy PN-EN ISO 14688, Biuletyn Państwowego Instytutu Geologicznego, 446 (2011)

18. A. Gołębiewska, Polska klasyfikacja według PN-B02480:1986 zgodna $\mathrm{z}$ wymaganiami PN-EN ISO 14688, Acta Scientiarum Polonorum, Architectura, 11, 3 (2012)

19. M. Tarnawski, Zharmonizowanie klasyfikacji gruntów spoistych według norm PN-EN ISO 14688:2006 i PN-86/B-02480, Przegląd Geologiczny, 65, 10/2 (2017)

20. Polish Standard PN-B-02480:1986 Grunty budowlane - Określenia, symbole, podział i opis gruntów 